\title{
BLESSED ARE THE PEACE MAKERS: Guidelines for Inter-Religious Living
}

John Martin Sahajananda*

\begin{abstract}
"Blessed are the peace makers for you shall be called children of God" (Mt 5,9), said Jesus. Jesus Christ was the child of God because he was the peace maker. He brought the message of peace to the world. He invited everyone to become the child of God and bring peace to the world. St. Paul says:
\end{abstract}

(...) but now in Christ Jesus you who were once far off have been brought near by the blood of Christ. For he himself is our peace, who has made both one and had broken down the middle wall of separation. Having abolished in his flesh the enmity, that is, the commandments contained in ordinances, so as to create in himself one new man from the two, thus making peace. And that he might reconcile them both to God in one body through the cross, thereby putting to death enmity. And he came and preached peace to you who are far off and to those who are near. For through him we both have access by one Spirit to the Father (Ephesians 2,13-18).

When we read these words of St. Paul we surely feel that they are more of an expression of intense of joy of experiencing Jesus Christ as the messenger of peace.

\footnotetext{
" Shantivanam belongs to the Congregation of Camaldolese in the Order of St.Benedict. Sahajananda has obtained a Licentiate in Spirituality from the Gregorian University, Rome. Today he is a spiritual director in the ashram. He is frequently invited to Europe to give lectures, retreats and seminars and to share his unique vision of Christianity for the third millennium. He has written many books and articles, including". A short comparative study between Shankara and Maître Eckhart" (2005) and "Four O'clock Talks: discussions with John Martin Sahajananda" (2007). Karur/India.
} 
What these passages tell us are: Jesus Christ is peace; he has broken down the wall of separation; those who are far and near are brought together; he has transcended the commandments, the Law; he created one new human being in the place of two (Jews and the Gentiles); he reconciled the whole of humanity to God; he came to preach peace to everyone; now everyone has access to the Father by one Spirit.

This is a marvelous vision of Christ that St. Paul presents to us. But when we look at the reality in the world we discover that human beings are divided in the name of Jesus Christ. Our misunderstanding and misinterpretation of Jesus' message is not only a source of division among the world religions but also a source of division among the Christians. The greatest scandal of Christians is that they are all divided in the name of Jesus Christ. There are thousands of Christian denominations in the world and there are mushrooming every day. How is that, a person who came to break down the walls of separation has become the source of separation? How is that, a person who brought the message of peace has become the source of conflict and violence? This is the important question every Christian Church and every Christian have to ask. If the proclamation of the message of Christ is dividing human beings, then we, Christians, need to introspect the way we have interpreted the message of Christ and presenting it to the world.

In order to understand the message of Christ and his work of reconciliation we need to understand his spiritual growth. There are many important moments in the life of Jesus. Each one is a turning point in his spiritual evolution to dedicate his life to do the will of God. We can take four important moments that are significant in his life before his crucifixion, death and resurrection.

The first moment was his birth as a human being through his physical mother, Mary. She conceived him, nourished him, protected him in her physical womb and then gave birth to him as a human being. In that sense Jesus was a hundred percent human being. As a human being we can say that he is a son of God, as every human being is a son of God or a daughter of God. Here the expression son of God, as a masculine gender, is more metaphorical than metaphysical.

The second moment was the day of his circumcision. On the eighth day of his birth Jesus was circumcised according to the Jewish tradition. With this Jesus became a Jew. He was not only a human being but also a Jew. He entered into the collective consciousness of Judaism. He lived like 
a Jew. He worshipped God like a Jew, he ate like a Jew and he spoke like a Jew. In that sense he was a hundred percent Jew. Judaism was his truth, his way and the model for his life. As a Jew he might have said that Judaism was his way, his truth and his life. As a Jew he was a collective son of God. If Jesus were a woman we might have called him a collective daughter of God. In this level gender is only a projection of the physical into spiritual level. It is also metaphorical than metaphysical. In the Old Testament we read when God says: I have called my son out of Egypt. Here the son refers to the whole people of Israel. It refers to the collective identity and the expression 'son' is metaphorical.

As he grew in his spiritual tradition he began to discover its limitations. Discovering the limitations of one's spiritual tradition is sign of maturity and growth. The first limitation was that his religion, at that time, divided human beings into two: the Jews and the Gentiles. So there was a wall between the Jews and the Gentiles. The second limitation was that God was understood only as the God of the Jews and not of the Gentiles. So there was again a wall between God and the Gentiles. The third limitation was that the external Law took the place of God and human beings were at the service of the Law, or religion. The fourth limitation was that God was a transcendent mystery inaccessible to human beings except through the mediation of the Prophets or the Commandments. The fifth limitation was that his religion created an exclusive collective consciousness thus becoming a source of enmity, conflict and violence.

This realization brought Jesus to the third important moment of his life which was his baptismal experience. The baptismal experience of Jesus was a moment in which he came out of the womb of Judaism and entered into the universal presence of God. It was his spiritual rebirth. God Himself validated this birth with the words 'you are my beloved son'. First he came out of the physical womb of his physical mother, Mary, and now he came out of his religious womb, Judaism. In this experience the wall between the Jews and the Gentiles was broken down and a new human being was born. It was the birth of a new human consciousness which was united with the whole of humanity and the whole of creation. This new human consciousness was neither a Jew nor a Gentile but the child of God or the Son of God. It was the birth of Universal Consciousness which embraced the whole of humanity and the whole of creation. In this experience the wall between God and the Gentiles was also broken down and God became the God of the whole of humanity and of creation and not just the God of the Jews. 
God was not only a transcendent mystery but also an indwelling presence, Emmanuel. The Spirit of God descended upon Jesus and God lived in him and he lived in God. Jesus said, "I am in the Father and the Father is in me" (Jn 14,11). He also said: "I am the way, the truth and the life. No one can come to the Father but through me" (Jn 14,6-7). This statement has to be understood in the contest of the New Covenant that God promised to the Jewish people. God gave them Ten Commandments to regulate their lives. But their relationship with God was oscillating between faithfulness and unfaithfulness. It was a turbulent relationship. So God promised that he would make a new covenant with the people so that everyone would follow the will of God without being told.

The days are surely coming, says the Lord, when I will make a new covenant with the house of Israel and the house of Judah. It will not be like the covenant that I made with their ancestors when I took them by the hand to bring them out of the land of Egypt - a covenant that they broke, though I was their husband, says the Lord. But this is the covenant that I will make with the house of Israel after those days, says the Lord: I will put my law within them, and I will write it on their hearts; and I will be their God, and they shall be my people. No longer shall they teach one another, or say to each other, "Know the Lord," for they shall all know me, from the least of them to the greatest, says the Lord; for I will forgive their iniquity, and remember their sin no more (Jer 31,31-34).

This is not really a New Covenant but we can call it 'eternal covenant' written in the heart of human beings when God creates them.

The Baptismal experience of Jesus was the inauguration of this New covenant, new human consciousness. God did not give Jesus any commandments, even the two great commandments, the love of God and the love of neighbor, but God said "you are my beloved son". This is writing the Law in the heart of Jesus. In the New Testament God speaks only twice: at the moment of Jesus baptism and at his transfiguration. On both occasions God said the same thing: You are my beloved son' and 'He is my beloved son'. Then God became silent because there was nothing more to say. In the first covenant God told people what they should and should not do but in the New Covenant God tells who human beings are. That self knowledge becomes the way, the truth and the life and human beings have to live from this inner wisdom and no more from the external commandments. We can speak of a quantum leap in the divine-human relationship. In the first covenant the external Law or religion becomes 
the way, the truth and the life and in the New Covenant, a human being will say: 'I am the way, the truth and the life'. So the baptismal experience of Jesus was the birth of New Covenant or New Human consciousness. It is the birth of the Son of God or the Daughter of God. Again the expressions 'the Son of God' and 'the Daughter of God' are metaphorical than metaphysical. We project our physical realities as the symbols of our spiritual experiences. A son of God or a daughter of God lives for himself or herself; a collective son of God or daughter of God lives for his/her collective identity. The Son of God or the Daughter of God lives for the whole of human kind and the whole of creation.

This new human consciousness breaks down the wall of division between the Jews and the Gentiles (all collective groups) and creates one God, one creation and one human kind. It breaks down the artificial wall of division between God and the Gentiles and God becomes the God of all. It creates one human kind out of two (many). It brings together those who are far and those who are near. It is the consciousness of peace. It reconciles the whole of human kind to God. Since this consciousness is one through it everyone has the access to God by one Spirit. This consciousness is peace and preaches peace to everyone. So when St. Paul is speaking of Jesus as the messenger of peace he is speaking of the New Covenant that Jesus experienced. The experience of the New Covenant is the discovery of our image and likeness of God. It is going back to our original and natural state.

The first covenant creates exclusive collective consciousness in which first comes religion, second comes God as understood by that religion and third come human beings who have to serve God in that religion. In this sense human beings are under the control and guidance of religions. Religions demand not only submission of will and intellect but also exclusive loyalty. In the New Covenant first comes God who is greater than religions and human beings; second come human beings, in their deepest level, who transcend religions and third come religions which are meant to be at the service of human beings and not human beings at the service of religions. Jesus said, "the Sabbath is made for human beings and not human beings for the sake of the Sabbath". The Sabbath is the symbol of religion. The collective consciousness of religions brings forth collective sons of God or daughters of God but the New Covenant brings forth Universal Son of God or Daughter of God. Jesus Christ, as a human being, is a son of God. As a Jew he is a collective son of God. After his baptism 
he realizes himself as the Son of God, the Universal Human Being, who is the way to God. So 'a son of God' grows into 'the Son of God'. This New Covenant does not demand the submission of will and intellect but the collective will and intellect are elevated to the universal will and intellect. This universal consciousness does not demand any submission of will and intellect or loyalty because there are no more groups there but unity. Jesus said, "Just as Father has life in himself, he has granted the son to have life in himself "(Jn 5,26). I have come to give life and give it abundantly"(Jn 10,10). The New Covenant does not demand submission of will and intellect or loyalty bus gives life. It is the Law written in the heart. Here a person experiences the God of freedom and silence. Loyalty and disloyalty belong to the collective consciousness. In the collective consciousness God is experienced as the God of authority and commandments. Where there is only unity loyalty and disloyalty have no place.

St. Paul says that "but now in Christ Jesus you who were once far off have been brought near by the blood of Christ". The blood of Jesus at this point is internal. Blood is the symbol of life, a separate identity, which creates a boundary. Jesus offered or sacrificed every identity that separated him from others and from God and in him he brought everyone together. 'Having abolished in His flesh the enmity, that is, the commandments contained in ordinances, so as to create in himself one new man from the two, thus making peace'. Here' the flesh' again is internal. The Law divided humanity and created enmity between the Jews and non-Jews. He transcended the life conditioned according to the external law and discovered the Law written in his heart. Thus he created one new human being in the place of two (at that time Jews and Gentiles) and made peace. "And that he might reconcile them both to God in one body through the cross, thereby putting to death to enmity". This cross again is internal. The Cross of Jesus is that which removes all divisions and puts to death enmity. It is the symbol of Truth, Unity and Peace. It creates one God, one creation and one human kind. Crucifixion has two meanings: from the side of Jewish religious authorities or political authorities and from the side of Jesus. ${ }^{1}$ From the side of Jewish spiritual leaders or the political authorities, it is the refusal to grow into unity. They decided to remain in their collective and divisive consciousness. From the side of Jesus it is affirming to remain at the universal consciousness and refusal to conform himself to the divisive consciousness. He wanted his spiritual tradition to

\footnotetext{
${ }^{1}$ We do not know who is really responsible to the death of Jesus, religious or political.
} 
grow from the first covenant to the New Covenant, according to the plan of God. He also wanted that the people be freed from the oppressed political and economic structures according to the vision of the kingdom of God. Hence the blood of Jesus, the flesh of Jesus and the cross of Jesus refer to the same process of breaking down the walls of separation. His vision of the kingdom of God, in a way, destabilized the existing power structures both religious and political and put Jesus in conflict with those structures. In this sense we can say that Jesus Christ died for spiritual growth, for unity and for breaking down the barriers between the collective groups. He died for the liberation of human beings from all the oppressive structures. He consciously offered his life for the unity and liberation of mankind.

To reduce the universal message of Jesus into collective consciousnesses is to crucify the Truth or to reject Jesus Christ. To refuse to grow from the collective consciousnesses into universal consciousness is to crucify the Truth or to reject Jesus Christ. If this is so then Christians cannot escape the guilt of refusing Jesus Christ as they have reduced Jesus teaching into different collective consciousnesses. In the letter to the Galatians St. Paul again says. "For as many of you as were baptized into Christ have put on Christ. There is neither Jew or Greek, there is neither slave nor free, there is neither male nor female; for you are all one in Christ Jesus" (Gal 3,27-28). To be baptized into Christ is to go from the divisive consciousness into universal consciousness. In the letter to Colossians he says, "And you have put on the new man who is renewed in knowledge according to the image of Him who created him. Where there is neither Greek nor Jew, circumcised nor uncircumcised, barbarian, Scythian, neither slave nor free, but Christ is all in all" (Col 3,11).

This new consciousness is no other than discovering our image and likeness of God; it is being renewed in knowledge according to the image of him who created him. It is discovering our original state, it is returning to the Garden of Eden. The New Covenant is not really new but 'eternal covenant' written in the heart of every human being as he or she is created by God. Religions, scriptures, mediators came after the fall of humanity. Before that they did not exist. So to be baptized into Christ is to enter into our original state, original consciousness. The consciousness of Jesus Christ at the universal level is no other than the consciousness of our original image and likeness of God. It brings back the fallen human consciousness to its original state. In him the whole of humanity and of creation enter into the presence of God. In and through him, this universal consciousness, 
we all have access to God, the Father, in one Spirit. In this consciousness there is neither Jew nor Christian, neither Muslim nor Hindu, neither Buddhist nor Jain, neither Indian nor Chinese, neither European nor NonEuropean, neither North American nor South American, neither Arab nor African, neither Asian nor Australian, neither Male nor Female. All are one in that nameless consciousness. It is going beyond all artificial labels. The name of Jesus is beyond all names (Phil 2,9). It is beyond all divisions. Only in and through this name there is access to God. There is salvation. To discover our image and likeness of God is to discover that we were the first born of creation. It is to discover that there is something in us which is beyond the manifested world, beyond time and space. It is the breath of God breathed into our earthen vessel, our body (Gen 2,7). St. Paul describes this very beautifully again in the letter to the Colossians when he speaks of Christ. He says:

He is the image of the invisible God, the first-born of all creation; for in him all things were created, in heaven and on earth, visible and invisible, whether thrones or dominions or principalities or authorities - all things were created through him and for him. He is before all things, and in him all things hold together. He is the head of the body, the church; he is the beginning, the first-born from the dead, that in everything he might be pre-eminent. For in him all the fullness of God was pleased to dwell, and through him to reconcile to himself all things, whether on earth or in heaven, making peace by the blood of his cross (Col 1,15-20).

Jesus Christ had to sacrifice his limited, divisive consciousness and enter into this eternal and universal consciousness where he became all, reconciled all things to God, and brought peace in the world.

The fourth important moment in the life of Jesus was when he grew one step further and realized that God and he were one. He declared: 'the Father and I are one'. This was the last stage of his ascending journey to God. Jesus Christ, not only, entered into our original image and likeness of God but went beyond that and discovered that he was one with God. St. John says, 'In the beginning was the word, the word was with God and the word was God' (Jn 1,1). At this level Jesus' consciousness is one with God and the life he lives is the life of God. At this level God is the way, the truth and the life. We can say that Jesus grew from the individual identity to the collective identity, from the collective to the divine identity. This growth is also the growth in the love of God and the love of neighbor. It begins with 
the individual love of God and neighbor and grows into the divine love of God and neighbor. RELIGION, with capital letters, means to relink with God. It takes us from in the individual to the collective, from the collective to the universal, and from the universal to the divine. Religions, as belief structures, belong to the second level, to the collective consciousness. RELIGION, with the capital letters, includes religion, but transcends them. In this sense religions can be many but RELIGION is one.

\section{Inter-Religious Dialogue and Beyond Dialogue}

Jesus proclaimed the good news of the 'the kingdom of God'. He began his ministry saying, 'the kingdom of God is at hand, repent' according to Mark (Mk 1,14-15), or 'repent, for the kingdom of heaven is at hand' according to Mathew (Mt 3,2). It is the experience of the New Covenant and finally experience of oneness with God. It is the experience of the radical love of God and love of neighbor. It is one hundred percent love of God and one hundred percent love of neighbor born from the realization of oneness of being rather than acquired from inner striving. When Jesus said, 'the Father and I are one' (Jn 10,30), he was revealing the radical love of God. When he said 'whatever you do to the least of my brothers and sisters that you do unto me' (Mt 25,40), he was revealing the radical love of neighbor. This is the experience of the kingdom of God. If people are living at the level of religions, first comes religion, second comes God as understood by that religion and third come human beings who have to serve God in the religions. Followers of religions may think that they have the mission to protect their religious boundaries, to expand their boundaries and increase their numbers. They may be willing even to die for the sake their belief structure and even kill others for the sake their belief structure. Conversion at this level is from one collective consciousness to another collective consciousness. This level becomes a source of conflict and violence in the world. In the kingdom of God, God comes first, second come human beings and third come religions which are meant to be at the service of human beings. The New Covenant does not abolish the religions or collective conscious nesses but fulfills them. Human beings cannot begin their spiritual life with the New Covenant but they have to begin with religions or belief structures and then grow into the New Covenant. Jesus said' 'I have not come to abolish the Law but fulfill it' (Mt 5,17). Jesus transformed religions into a nest in which human beings are protected, nourished, given security, until they are ready to move into 
the universal consciousness of the kingdom of God; until they are born as the son or the daughter of God. Conversion at this level is not from one collective consciousness (religion) to another collective consciousness (religion) but from collective consciousness to the universal consciousness, from the collective son of God to the Son of God. When Jesus spoke of repentance he meant as a transition from the collective consciousness to the universal consciousness.

Inter-religious dialogue is happening at the level of belief structures or religions or collective consciousness. We cannot bring unity at this level. Any unity that comes at that level would be artificial. The goal is to transcend or outgrow the belief structures and discover our original image and likeness of God in which we discover our original unity with the whole of humanity and of creation. In that original unity all artificial divisions will be broken down and we discover one God, one creation and one human kind. It means going beyond religions and beyond inter-religious dialogue. This is real 'metanoia' or 'repentance', going beyond the divisive consciousness. It is discovering one human kind out of many collective groups. It is becoming 'the Son of God' or 'the Daughter of God'.

Jesus told Nicodemus: "unless you are born again you cannot enter into the kingdom of heaven. The wind blows where it wills but you do not know from where it comes and you do not know to where it goes. The person who is born of the spirit will be like this" (Jn 3,3; 3,8). Nicodemus was in the womb of his religion. He was in the collective consciousness. He was a collective Son of God. Jesus was inviting him to come out of his collective consciousness and enter into the universal consciousness, to become the child of God, the Son of God. This is the invitation of Jesus to all those who are in the womb of religions, in the collective consciousness. Jesus invited people 'to repent ${ }^{\prime 2}$, metanoia. This invitation is directed towards both the religious authorities and individuals. Religious authorities represent religions. So it is addressed to the religions. Metanoia or Repentance, when applied to religions, means that religions should not keep human beings in their wombs but should give birth to them into the universal consciousness, into the universal presence of God, as the children of God. Metanoia or repentance, when applied to individuals, is a process

\footnotetext{
${ }^{2}$ The english word 'repent' does not really communicate the propound meaning of the word 'metanoia'. Metanoia is to go beyond collective consciousness, beyond universal consciousness (nous) and discover unitary consciousness or divine consciousness. Repent is generally understood as, feeling sorry for one's sins, change of mind, change of life, doing penance etc., which do not communicate the meaning of 'metanoia'. Meta means beyond noia comes from the word nous. Nous in platonic philosophy is universal mind or universal consciousness. It is the logos in the gospel of St. John.
} 
in which a person comes out of the womb of religion and enters into the universal presence of God. A collective son is born as the Son of God. As long as human beings remain in the collective consciousness there will be always the possibility of violence and conflict in the world. People may try to find some consolation and artificial peace in the advocacy of tolerance and learning to live together with differences by promoting religious pluralism and cultural pluralism but these can never be a permanent solution. Violence may erupt at any time since where there is an essential boundary there is potential for war. People can never become instruments of peace as violence is inbuilt in every collective consciousness.

It is unfortunate that Christianity has reduced Jesus' message into one collective consciousness and thus separating itself from the other collective consciousnesses. In this way it has become a source of conflict and violence in the world. It still contributes for violence indirectly with its program of conversion. Christians think that they have the mission to convert people to Christ. But the mission Jesus gave to his disciples was not to convert people from one collective consciousness (religion) to another collective consciousness but from the collective consciousness to the universal consciousness. Where there is mission or ambition to expand one's boundary and increase one's numbers there is inner violence and this inner violence brings also external violence. With this inner violence one cannot become an instrument of peace. Jesus Christ did not have a mission or an ambition to expand his boundary and increase his numbers. His mission was to tell everyone that they are already in the kingdom of God. They need only to realize this truth. The conversion which Jesus proposed was not from one religion to another religion but from religions into the universal presence of God. Christians may be surprised if they discover that they also need 'metanoia'. The call of Jesus to Christianity would be 'to repent' or 'metanoia' from its collective consciousness to universal consciousness, from its collective truth to the universal truth, from collective Jesus Christ to universal Jesus Christ. Only then Christians can call themselves the Children of God or the Sons of God or the Daughters of God". Only then can they become instruments of peace and unity. Jesus prayed for this unity when he said: "May they all be one, just as, Father, you are in me and I am in you, so that they all may be in us so that the world may believe it was you who sent me" (Jn 17,21).

Peace and unity are available to us as freely as the Sun light is available during the day. This is what Jesus meant when he said that 'the kingdom 
of God is at hand'. It means that God is everywhere. We need to 'repent' in order to enter into it. It is to come out of our collective consciousnesses. If we enclose ourselves in our four walls of collective consciousnesses and search for peace and unity, how can we find them? How can we become the instruments of peace? The call 'to repentance' is to both religions and individuals. Religions need to repent and give possibility to the individuals to repent. Do religions have the courage to respond to the call of God and 'repent' which means to give birth to their followers into the universal consciousness, into sons and daughters of God, and thus becoming mothers to the children of God? Do they have courage to become instruments of peace and unity? Do we, as individuals, have the courage 'to repent' which means to come out of the womb of religions and enter into the universal presence of God, to become the sons and the daughters of God and thus becoming the instruments of peace and unity? If religions repent that is the celebration of Christmas. If human beings repent that is the celebration of Easter. If both, religions and human beings are cooperating with each other then it is baptism of Jesus. These three archetypes reveal the same truth: the birth of a new human consciousness, the birth of the Son of God or the Daughter of God, the inauguration of the new covenant, discovering our original image and likeness of God. All of them proclaim the message of peace. This is really the essence of Christianity. "Blessed are the peace makers for they shall be called the children of God" (Mt 5,9).

\section{Guidelines for Inter-Religious Living}

Basing on the above presentation I would like to propose some guidelines for Inter- Religious Living:

1. To hold that God or Truth or Ultimate Reality is greater than our belief systems. It is like the infinite space. All religions and all individuals are inside this infinite space.

2. To accept that all the sacred scriptures, all religions and belief systems are a gift of God to human kind. They belong to common human heritage and not a private property of one particular religion. People should be free to read and learn from the other scriptures, other than their own, and not be tied down to any particular scripture.

3. To affirm the dignity of human beings that they are manifested in the image and likeness of God and they have the possibility to grow beyond belief structures. 
4. To stop all religious conversions. Religions should not have any desire to expand their boundaries or increase their numbers. Their only desire should be to facilitate the spiritual growth of their followers. They should facilitate the conversions from the collective consciousness to the universal consciousness. This is an internal process and not something external. Religions should be like fingers pointing towards God.

5. To see religious boundaries as functional boundaries and not as essential boundaries. If religious boundaries are seen as essential the result would be the possibility of violence. Where there is an essential boundary there is a need for protection and there is a potential for war.

6. To love one's religion sincerely and to grow in the deeper understanding of one's religion and live the precepts of one's religion authentically. This will help one to realize that others also love their religions, and respect others' religions.

7. To realize the limitations of ones' religion. Every religion is conditioned in time and space and there will be limitations in its understanding of the divine will. Only this realization will prepare one to have genuine dialogue with other religions.

8. To evaluate the precepts of one's religion in the mirror of human dignity and equality of the sexes.

9. To look at belief structures as nests in which human being are born, protected, nourished and given security until they are ready to move into the freedom of the universal consciousness.

10. To work together for the liberation of human beings from all oppressed structures: religious, political, social and economic and ecological.

11. To evaluate one's belief structures from the criteria of radical love of God and the radical love of neighbor.

12. To recognize that human beings are more important than religions and that religions should serve human beings to realize their full potentiality.

These are not exclusive. People also can suggest some other aspects that can be useful for inter-religious living. 